\title{
Macrothink
}

\section{Determinants of Consumer Complaining Behavior: A study of Pakistan}

\author{
Touqeer Ashraf \\ Department of Management Sciences, The Islamia University of Bahawalpur, Pakistan \\ touqeerashraf@hotmail.com
}

Waseem Sajjad

Department of Management Sciences, The Islamia University of Bahawalpur, Pakistan

\author{
Muhammad Rizwan \\ Lecturer, Department of Management Sciences \\ The Islamia University of Bahawalpur, Pakistan \\ E-mail: rizwan.arshad@iub.edu.pk
}

Dilshad Ahmed

Department of Management Sciences, The Islamia University of Bahawalpur, Pakistan

Haseeb Nazeer

Department of Management Sciences, The Islamia University of Bahawalpur, Pakistan

DOI:10.5296/ ijld.v3i6.6209 URL: http://dx.doi.org/10.5296/ ijld.v3i6.6209

\begin{abstract}
Importance of addressing dissatisfied consumers has increased very much these days because of intense competition due to establishment of new kind of stores and offering many kinds of customer services by service providers. This study focuses on effects of attitudinal and perceptional variables (attitude toward complaining, prior complaint experience, perceived possibility of success and customer's loyalty) on Consumer Complaining Behavior (CCB). Model of this research is to complete the attitudinal or behavioral perspective and consumer complaining behavior literature in the frame work. A total of 232 people were asked to become the part of this study through a self administered questionnaire from Bahawalpur City.
\end{abstract}


This study uses a non-probability sampling technique that is convenience sampling. Regression results shown that attitude toward complaining, perceived possibility of success and customer loyalty had significant positive impact on consumer complaining behavior but relation between prior complaint experience and CCB was not proved to be significant. Careful studies have been carried out in order to validate conceptual frame-work that can be taken as an initial point to understand the concepts of Consumer Complaining Behavior (CCB).

Keywords: Consumer complaining behavior (CCB), Attitude, Loyalty, Complaints, Customer Satisfaction

\section{Introduction}

Management has always tried to reduce the complaints because complaints have always been taken to be negative response from the customers. Modern studies in marketing have revealed that this response from customers is beneficial for the companies (Phau \& Sari, 2004). Marketers call it "Indispensible indicator of unsatisfactory performance" (Phau \& Sari, 2004). Companies have started paying a lot of attention towards listening to the complaints of the customers because of such researches. Consumers, as a result of dissatisfaction from service failure, have become more confident to complain to their service providers. If service providers do not handle those complaints appropriately, frustration, dissatisfaction and negative reaction of consumer may rise and become strong enough to harm marketer's reputation. Unhappy and frustrated consumers communicate about their negative experience to an average of 9 other persons, and 10 to $15 \%$ firm's sale losses can be accounted for by these frustrated consumers (TARP, Measuring the grapevine consumer response and word of mouth, 1981).

Behavioral or non behavioral response shown by the consumer when they perceive dissatisfaction in a shopping and/or consumption experience is called Consumer Complaining Behavior (CCB) (Singh, consumer complaint intention behavior: definitional and taxonomical issue, 1988). Most of the researchers are conducted on only behavioral responses and these researches mostly identify these behavioral responses as results of dissatisfaction, classifying them according to addressee. These classes include private responses (also known as market oriented actions) and Public responses (also known as actions oriented at the company). Private actions consist of word of mouth comments and switching behavior of consumer while complaining to third parties who are present in each business transaction, are complaints to manufacturers of product, distributors or government. Other than these complainants, there are people who do not complain whatever the problem is. Interaction style of people who do not complain in any case is termed as politeness. Due to this kind of interaction style, people refrain from confronting retailer.

Customer's reaction to service failure is affected by many factors such as level of dissatisfaction (Mittal, Huppertz, \& Khare, 2008), the likelihood of service recovery (Blodget $\&$ Granbois, 1992), the ease of process of complaining (Blodget \& Anderson, 2000), and the 
perception that whether or not company will respond back (Huppertz, 2007). Other factors may include current relationship of consumer with the company (Hui, Ho, \& Wan, 2011) and consumer's attitude toward complaining (Kim, Kim, Im, \& Shin, 2003). Service failure may cause loss of customer loyalty; negative word of mouth (NWOM) said to others and in worst cases may decrease sales and profits of the company (Anton, Camarero, \& Carrero, 2007). Customers from different cultures show different complaining behavior as a result of service failure (Yuksel, Kilinc, \& Yuksel, 2006). Reasons of cultural influence includes: culture decides patterns of consumption, and what is acceptable in society (Steenkamp, Hofstede, \& Wedel, 1999). A large proportion of studies on consumer complaining have been conducted in Europe and USA, and now companies are increasing focusing on the consumers in Asian countries for this research. Consequently, companies need to identify those attitudes and behaviors that affect the complaining behavior of this increasingly important group of Asian people.

In past few years, major focus of studies related to consumer complaining behavior have been the transactions in the services businesses because services businesses have spread very fast worldwide in these years (Chan \& Wan, 2008). There is a difference between complaining behaviors of Western and Asian people because Western people belong to Individualistic culture and Asian people belong to Collectivist culture. In contrast to Western people, Asian people, In case of service failure, do not normally complain and they are more likely to switch to some other company, and they spread negative word of mouth about the previous company (Chan \& Wan, 2008). When we explain the difference between likelihood of complaining in collectivist and individualistic cultures, we find that social harmony is a major determinant but social harmony fails to explain such complaining behaviors when other cultural values are also studied. Psychological and communication literature, for instance, reveals that face concerns are more important to study in conflict management (Cocroft \& Ting-Toomi, 1994). Definition of Face, a positive social value a person wants for himself, describes that in individualistic as well as collectivist culture, being socially accepted is the fundamental need of every person (Hwang, Francesco, \& Kessler, 2003).

Consumer complaining behavior effects repurchase intension of consumer, their brand loyalty, service recovery by the company, and negative word of mouth spread by consumers through such complaints; and these are the basic reasons of increasing interest in study of consumer complaining behavior. Service failure can change good relationship between consumer and producer into a bad one. Loyal consumers who have strong bonding with the company accept the service failure anyways, and help the organization to improve the service next time (Nicholson, Compeau, \& Sethi, 2001).

Studies conducted on consumer complaining behavior mostly identify only determinants of consumer complaining behavior and consumer complaining behavior as a result of these determinants which cannot be predicted in terms of attitude and perception. Role of attitudinal and perceptional variables has not been focused in explaining consumer complaint behavior. Purpose of this study is to find impact of these variables - specifically customer loyalty, prior complaint experience, perceived possibility of success and attitude toward complaint behavior - on complaint behavior intention. 
Loyal customers are those who do not value prices and they do not switch to competitors' products or substitutes in case of product/service failure. They always have positive attitude towards company. Prior complaint experience can be conceptualized as a consumer's tendency to appeal again in case of dissatisfaction. Perceived likelihood of successful complaint is defined as the perceived probability of getting reward such as a refund, exchange, or apology through complaining to the firm. Attitude toward complaining behavior is defined as the personal tendency of dissatisfied consumers to seek compensation from the firm.

\section{Literature Review:}

\section{Consumer complaining Behavior}

Consumer Complaining Behavior (CCB) can be defined as a number of responses which result from product/service failure and cause dissatisfaction to consumer (Singh, consumer complaint intention behavior: definitional and taxonomical issue, 1988). Consumers may show different kinds of responses as a result of dissatisfaction; some may do nothing while others may take legal action against product/service provider (Huang, T., \& Wu, 1996). According to Hirschman (1970), two types of active negative responses resulting from dissatisfaction included voicing and exit behavior of consumer. In voicing, consumer complains directly to the service provider while exit behavior, consumer decides not to make any more business transactions with service provider (Singh, consumer complaint intention behavior: definitional and taxonomical issue, 1988). Based on Hirschman's (1970) voice, exit and loyalty (Loyalty being the deciding not to terminate the relationship with the company after any dissatisfaction) responses, Maute and Forrester (1993) suggested three categories of responses resulting from dissatisfaction. Day and Landon (1977) classified these responses into three categories which included, 'voicing to the service provider', 'Negative Word of Mouth (NWOM), and third party complaints such as complaints to someone who has some influence on the service provider. Empirical researches conducted by Singh (1988) suggested CCB to be from one of three categories which included voice responses (complaining directly to the service provider seeking service recovery), private responses (NWOM) and third party responses (taking legal actions). Rogers, Ross and Williams (1992) extended the studies of Singh (1988) and categorized CCB to be falling in one of following categories: change future behavior: change future behavior (terminate relationship with service provide), private complaining (spreading NWOM to friends and family, or directly complaining to product/service provider), third party (complaining to someone who has some influence on seller), or ignore product/service failure. Customers who decided not to complain were called "passive" by Singh (1988) "upset-no action" by Panther and Farquhar (2004). Yuksel (2006) supported concept given by Hirschman (1970) and said that customer's decision of not taking any action is actually loyalty. According to different writers, making complaints is actually taking some actions against the company as a result of dissatisfaction caused by product/service failure (Schouten \& Raaij, 1990). Quite often, complaining is taken to be cognitive reaction (TARP, 1985), sometimes it is called emotional incident (Krapfel, 1985) in which 'what is complained?' and 'how it is complained?' is clear. 


\section{Attitude toward complaining}

Attitude can be defined in terms of how a person generally sees a specific behavior negatively or positively, after evaluating results of an act (Fishbein \& Ajzen, 1975). Study of Psychological and Consumer Behavior literature reveals that a person's behavioral intention determines his attitude toward that particular behavior. Attitude toward complaining behavior is known as personal tendency of a dissatisfied customer seeking redress from the company (Richins, Consumer perceptions of costs and benefits associated with complaining, 1980). Generally, this attitude is thought to affect consumer complaining, whether 'good' or 'bad', and this attitude is not specific for a same kind of dissatisfaction (Singh \& Wilkes, 1996). A consumer is going to voice against dissatisfaction, or spread NWOM, is decided by his attitude toward complaining (Oh, 2004; Day, 1984). Customers who are certain about how to complain and/or who are confident enough to gain redress from the company are more expected to complain than the customers who are not sure about getting redress from the company (Bodey \& Grace, 2007). Research reveals that a person who has a positive attitude toward complaining is more likely to complain as a result of dissatisfaction (Richins, Consumer perceptions of costs and benefits associated with complaining, 1980) and studies show there exists an empirical relationship between attitude toward complaining and consumer complaining behavior (Kim, Kim, Im, \& Shin, 2003). Fishbein and Ajzen's (1975) attitude toward intention and behavior model proposed that a customer's attitude toward complaining directly effects complaint intention. Customers who have positive attitude toward complaining do not get involved in negative behaviors like negative word of mouth and exit intentions (Day \& Landon, 1976). In the same way, empirical evidences of "attitude toward and compensation seeking" and compensation seeking intentions are found (Richins, Consumer perceptions of costs and benefits associated with complaining, 1980). Customers who do not seek redress from the company are likely to involve in negative behaviors like switching to some other competitor or spreading negative word of mouth against the company (Blodget \& Granbois, 1992). Usually, customers who have positive attitude toward complaining are more likely to complain as compared to those who have negative attitude toward complaining (Bodey \& Grace, 2007).

\section{H1: Attitude toward complaining has a direct positive association with consumer complaining behavior.}

\section{Prior Complaint experience}

Prior complaint experience can be taken as likelihood that a person will complain again to same service provider to whom he had complained before in case of dissatisfaction (Singh \& Wilkes, 1996). Experience of complaining before can affect the attitude and behavior of the consumer in case of dissatisfaction in the future (Singh \& Wilkes, 1996). Experience of complaining affects attitude toward complaining. Customers build up positive attitude toward complaining when they learn about how to complain and benefits of complaining (Singh \& Wilkes, 1996). As the customer makes complaints more frequently, he becomes aware of more methods of complaining; his attitude toward complaining becomes stronger and he becomes more certain due to his knowledge and communication skills acquired through prior 
complaining which increases his expectation that he will become able to get redress from the firm (Jin, Determinants of customer's complaint intention, 2010). Usric (1985) suggests that a consumer who complains frequently develops more positive attitude toward complaining, gives more value to complaining and has higher possibility of success as compared to a person who does not complain frequently. According to Expectation Disconfirmation theory of consumer complaint behavior, expectation of consumer before complaining as result of dissatisfaction and satisfaction is determined by the amount of dissatisfaction (Oliver, 1997). When the customer feels dissatisfied, he becomes displeased and complains (Day \& Landon, 1977). Usually past experience of a customer with service provider in a business transaction affects his satisfaction in that particular transaction (Kim, Wang, \& Mattila, 2010). On the other hand, researchers believe that service failure experience is felt more severely by the customers who have high level of satisfaction in previous transactions (Bitner, Booms, \& Tetreault, 1990). Reaction of loyal customers is even stronger when they feel betrayed in a business transaction (Gregoire \& Fisher, 2008). Similarly, customers who do not have strong emotional attachment with company, forgive the company in case of service failure if the process of service recovery was appropriate (Mattila, 2004). Past experience has a positive impact on complaining behavior (Singh \& Wilkes, 1996). Past experience also affects the method of complaining and determines their effectiveness (Martin, 1991).

\section{H2: Prior complaint experience has direct positive association with consumer complaining behavior.}

\section{Perceived possibility of success}

Perceived possibility of success is defined as likelihood of getting redress such as a refund, exchange, or apology when a complaint is registered to a company (Singh, 1990a). According to Li Yin Jin (2010), perceived possibility of successful outcome is defined as customer's personal judgment of perceived benefit gained from complaining and perceived possibility of success. Customers are more expected to complain when they feel that there is a possibility that there complaint will be valued by the company. They will consider their complaints useless if they feel that the company will not value their complaints and hence, they will never complain. Literature reveals that responses of complaints by the company affects perceived possibility of success (Singh, 1990a). Studies shows that people show greater complain intention when they perceive high likelihood of success in complaining (Singh, 1990a). They become more likely to complain when they perceive high value of complaining, rather than getting involved in any other response (Morel, Posez, \& Wilke, 1997). According to Day and Landon (1976), perceived possibility of success has a direct positive impact on consumer complaining behavior.

\section{H3: Perceived possibility of success has a direct positive association with consumer complaining behavior.}

\section{Customer Loyalty}

Researchers and practitioners admit the high importance of Customer Loyalty as a basic concept (Eggert, 2000). Loyal customers are those who do not value prices and they do not 
switch to competitors' products or substitutes in case of product/service failure. They always have positive attitude towards company (Eggert, 2000). Generally, notion of loyalty is expressed by words such as dedication, commitment, reliability, perseverance, patience and it is used in subjects like sports team, family member, faith etc (Durukan, Gokdeniz, \& Bozaci, 2012).Additionally, when a person earns his income with difficulty in order to purchase the product of certain company, it is termed as loyalty (Brooks, 2010). Modern studies in Marketing are being carried out on studying the affect of effective complaint management on customer loyalty. In this context Yaping, Shaolong and Xing (2009) studied the affect of service recovery (explaining, communication, feedback and redress) on perceived justice and customer loyalty. On the other hand, effect of customer loyalty on consumer complaining behavior has not been studied extensively in the past. Fornell and Wernerfelt (1988) claimed that loyal customers complain more frequently as compared to non-loyal customers in case of dissatisfaction. Loyal customers do not switch to competitor companies straight away as a result of dissatisfaction; they choose to stay with the company and solve the problems (Oztopcu, 2006). Blodget and Granbois (1992) studied the model of Hirschman (1970) and revealed that loyal customers are more likely to seek redress from the company, less likely to switch to the competitors or to spread negative word of mouth in case of service failures. Similarly, loyal customers are less likely to complain to the third parties (someone who has influence on company) (Oh, 2003).

\section{H4: Customer loyalty has direct positive association with consumer complaining behavior.}

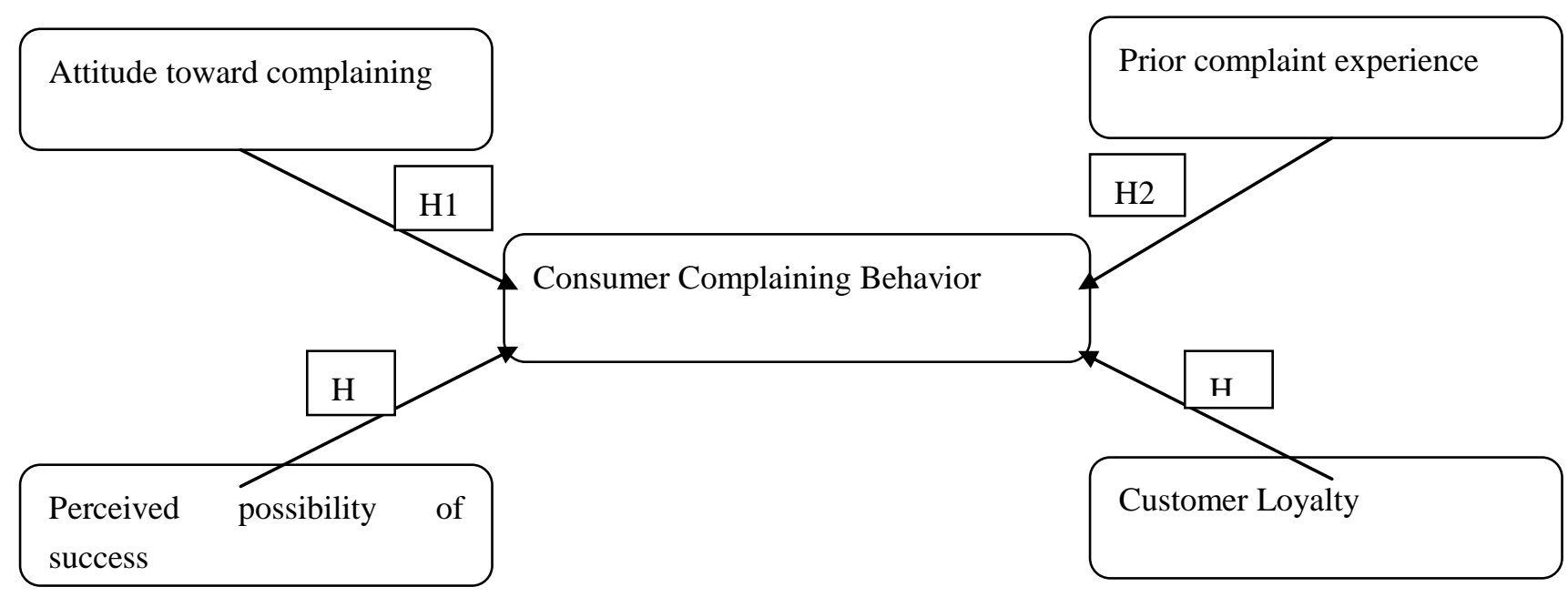

Research Model

\section{Research Methodology}

This research is descriptive in nature. Descriptive research can be defined as describing some particular phenomenon or situation and describes the current situation rather than interpreting and giving judgments (Croswell, 1994). Descriptive research is mainly used to verify the statement proposed in the hypothesis. This research gives the information latest information 
about the scene and is focused on present or past (Kumar, 2005).

\section{Sample/Data}

In order to understand consumer complaining behavior, a sample of 250 respondents will be asked to participate in a self-administered questionnaire. The population of this research is cell phone users in Pakistan.

This study utilizes convenience sampling which is a technique of non-probability sampling. Convenience sampling collects easily available relevant information from the sample (Zikmund, 1997). Convenience sampling is a less expensive method of collecting large amount of information in very less time (Lym et al., 2010).

We will select the sample members from Bahawalpur, a city of Pakistan. Two main clusters of people to collect sample data will be university students and business personals of the city. It will be ensured that sample members, who will become part of this research, should be using cell phones.

\section{Instruments and measures}

The survey instruments of current study address two main purposes. First is to analyze the relationship of different variables affecting consumer complaint behavior. Second, to collect information that can help us to understand changes among different classifications.

The survey instrument contains two sections. Section 1 includes different demographic variables that will collect information about gender, age, income, connection of Cell Phone Company and status of the respondent. Section 2 includes the latent variables that are important in current study. These variables include consumer complaining behavior, customer loyalty, prior complaint experience, attitude toward complaining and perceived possibility of success. The scales of the study were adopted from previous literature and published studies.

\begin{tabular}{|c|c|c|c|}
\hline No. & Variable & Items & Reference \\
\hline 1 & $\begin{array}{l}\text { Consumer } \\
\text { Complaining } \\
\text { Behavior }\end{array}$ & $\begin{array}{l}\text { 1. I find it bit embarrassing to complain. } \\
\text { 2. Complaining about unsatisfactory products is } \\
\text { my duty. } \\
\text { 3. The more frequently I have to use the } \\
\text { product, the more likely I am to complain if it } \\
\text { is faulty. } \\
\text { 4. Firms are usually willing to provide repairs } \\
\text { for faulty products. }\end{array}$ & $\begin{array}{l}\text { (Singh, } \\
\text { 1989) }\end{array}$ \\
\hline 2 & Prior Complaint & 1. I know about consumer rights. & $\begin{array}{l}\text { (Singh, } \\
\text { 1989), }\end{array}$ \\
\hline
\end{tabular}




\begin{tabular}{|c|c|c|c|}
\hline & Experience & $\begin{array}{l}\text { 2. I know about how to complain. } \\
\text { 3. I have complained about dissatisfaction in last } \\
\text { three months. }\end{array}$ & $\begin{array}{l}\text { (Singh, } \\
\text { 1990a) }\end{array}$ \\
\hline 3 & $\begin{array}{l}\text { Perceived } \\
\text { Possibility of } \\
\text { Success }\end{array}$ & $\begin{array}{l}\text { 1. If I complain about my dissatisfaction to the } \\
\text { company, the company will take appropriate } \\
\text { action. } \\
\text { 2. If I complain about my dissatisfaction to the } \\
\text { company, the company will take appropriate } \\
\text { action and will give better service in the } \\
\text { future. } \\
\text { 3. I f I complain about my dissatisfaction to the } \\
\text { company, the company will give better } \\
\text { service in the future and this will benefit other } \\
\text { consumers as well }\end{array}$ & $\begin{array}{l}\text { (Singh, } \\
\text { 1990a), } \\
\text { (Day, } \\
\text { Grabicke, } \\
\text { Schaetzle, \& } \\
\text { Staubach, } \\
\text { 1981) }\end{array}$ \\
\hline 4 & $\begin{array}{l}\text { Attitude toward } \\
\text { Complaining }\end{array}$ & $\begin{array}{l}\text { 1. When I have a problem with a product, even } \\
\text { if it is cheap, I usually complain, ask for a } \\
\text { refund or change the product. } \\
\text { 2. Normally I am reluctant to present a } \\
\text { complaint even if the product I have } \\
\text { purchased is no good. } \\
\text { 3. In general, I am more likely to complain, ask } \\
\text { for the refund or change the product than } \\
\text { other people I know. }\end{array}$ & $\begin{array}{l}\text { (Blodget, } \\
\text { Granbois, \& } \\
\text { Walters, } \\
\text { 1993) }\end{array}$ \\
\hline 5 & $\begin{array}{l}\text { Customer } \\
\text { Loyalty }\end{array}$ & $\begin{array}{l}\text { 1. This company would be my first priority. } \\
\text { 2. I consider myself to be loyal to this company. } \\
\text { 3. I will not buy connection of any other } \\
\text { company if connection of this company is } \\
\text { available. } \\
\text { 4. I recommend this company to someone who } \\
\text { seeks my advice. } \\
\text { 5. I get good value of my money. } \\
\text { 6. I say positive things about this company to } \\
\text { other people. } \\
\text { 7. I am willing to pay premium price over } \\
\text { competing products to be able to purchase }\end{array}$ & \\
\hline
\end{tabular}




\begin{tabular}{|l|l|l|}
\hline & this connection again. & 8. \\
& $\begin{array}{l}\text { I consider this connection my first priority in } \\
\text { next few years. }\end{array}$ & \\
\hline
\end{tabular}

\section{Procedure}

The questionnaire was distributed among 280 respondents in Bahawalpur. The respondents were selected on the basis of criteria above mentioned. Before giving the questionnaire, the purpose of study and questions were explained to respondents so they can easily fill questionnaire with relevant responses. A total of 232 questionnaires were selected and the rest of questionnaires were not included in the further analysis due to incomplete or invalid responses. After collecting the completed questionnaires, these questionnaires were coded and entered into SPSS sheet for further analysis.

\section{Reliability Analysis}

Cronbach's alpha of Consumer Complaining Behavior questionnaire items, which are more than acceptable and recommended value 0.50 by Nunnally (1970), are given below:

\begin{tabular}{|l|l|l|}
\hline Scales & Items & Chronbach Alpha \\
\hline Consumer Complaining Behavior & 4 & 0.538 \\
\hline Attitude toward Complaining & 3 & 0.532 \\
\hline Prior Complaint Experience & 3 & 0.861 \\
\hline Perceived Possibility of Success & 3 & 0.813 \\
\hline Customer Loyalty & 8 & 0.846 \\
\hline
\end{tabular}

\section{Results and Analysis}

Personal and demographic information such as gender, age, income, status, and connection of cell phone company of the respondent are presented in following table:

\begin{tabular}{|l|l|l|l|}
\hline Variable & Category & Frequency & Percentage \\
\hline Gender & Male & 148 & 63.8 \\
& Female & 84 & 36.2 \\
\hline Age & Below 20 years & 71 & 30.6 \\
\hline
\end{tabular}




\begin{tabular}{|c|c|c|c|}
\hline & $\begin{array}{l}20-30 \text { years } \\
30-40 \text { years } \\
\text { Above } 40 \text { years }\end{array}$ & $\begin{array}{l}127 \\
23 \\
11\end{array}$ & $\begin{array}{l}53.7 \\
9.9 \\
4.7\end{array}$ \\
\hline Income & $\begin{array}{l}\text { Below Rs. } 10000 \\
\text { Rs. } 10000-20000 \\
\text { Rs. } 20000-30000 \\
\text { Rs. } 30000-40000 \\
\text { Above Rs. } 40000\end{array}$ & $\begin{array}{l}132 \\
40 \\
14 \\
13 \\
33\end{array}$ & $\begin{array}{l}56.9 \\
17.2 \\
6.0 \\
5.6 \\
14.2\end{array}$ \\
\hline Connection using & $\begin{array}{l}\text { Mobilink } \\
\text { Telenor } \\
\text { Warid } \\
\text { Ufone } \\
\text { Zong }\end{array}$ & $\begin{array}{l}88 \\
33 \\
36 \\
57 \\
18\end{array}$ & $\begin{array}{l}37.9 \\
14.2 \\
15.5 \\
24.6 \\
7.8\end{array}$ \\
\hline Status & $\begin{array}{l}\text { Student } \\
\text { Employee } \\
\text { Businessman } \\
\text { Others }\end{array}$ & $\begin{array}{l}147 \\
46 \\
30 \\
9\end{array}$ & $\begin{array}{l}63.4 \\
19.8 \\
12.9 \\
3.9\end{array}$ \\
\hline
\end{tabular}

\section{Hypothesis testing}

\section{Attitude toward Complaining}

Regression results of this study confirms the significant positive relationship between Attitude toward Complaining and Consumer Complaining Behavior with $(\beta=0.240)$ and $(\mathrm{p}<$ 0.05 ). According to these results, Attitude toward Complaining contributes $24 \%$ to Consumer Complaining Behavior. These results of study validate $\mathrm{H} 1$.

\section{Prior Complaint Experience}

Regression results of this study do not show any significant relationship between Prior Complaint Experience and Consumer Complaining Behavior because of ( $p>0.05$ ). This result does not validate $\mathrm{H} 2$. 


\section{Macrothink}

International Journal of Learning \& Development

ISSN 2164-4063

2013, Vol. 3, No. 6

\section{Perceived Possibility of Success}

Regression result of this study confirms the significant positive relationship between Perceived Possibility of Success and Consumer Complaining Behavior with $(\beta=0.285)$ and $(\mathrm{p}<0.05)$. According to these results, Perceived possibility of success contributes more than $28 \%$ to Consumer Complaining Behavior. These results validate H3.

\section{Customer Loyalty}

Regression results of this study confirms the significant positive relationship between Customer Loyalty and Consumer Complaining Behavior with $(\beta=0.244)$ and $(\mathrm{p}<0.05)$. According to these results, Customer loyalty contributes more than $24 \%$ to the Consumer Complaining Behavior. Results of this study validate $\mathrm{H} 4$.

Following Table summarizes the regression results of the study:

\section{Regression Results}

\begin{tabular}{|l|l|l|l|l|l|l|}
\hline Hypothesis & Model Variables & Estimate & S.E & C.R & P & Results \\
\hline H1 & Attd_Cmpln $\rightarrow$ CCB & 0.240 & 0.063 & 3.668 & 0.000 & Supported \\
\hline H2 & Pr_Cmpln $\rightarrow$ CCB & -0.082 & 0.032 & -1.487 & 0.139 & $\begin{array}{l}\text { Not } \\
\text { Supported }\end{array}$ \\
\hline H3 & Prcv_Sxs $\rightarrow$ CCB & 0.285 & 0.053 & 4.699 & 0.000 & Supported \\
\hline H4 & Cstmr_Lylty $\rightarrow$ CCB & 0.244 & 0.063 & 4.084 & 0.000 & Supported \\
\hline
\end{tabular}

\section{Graphical Presentation of Structural Model}

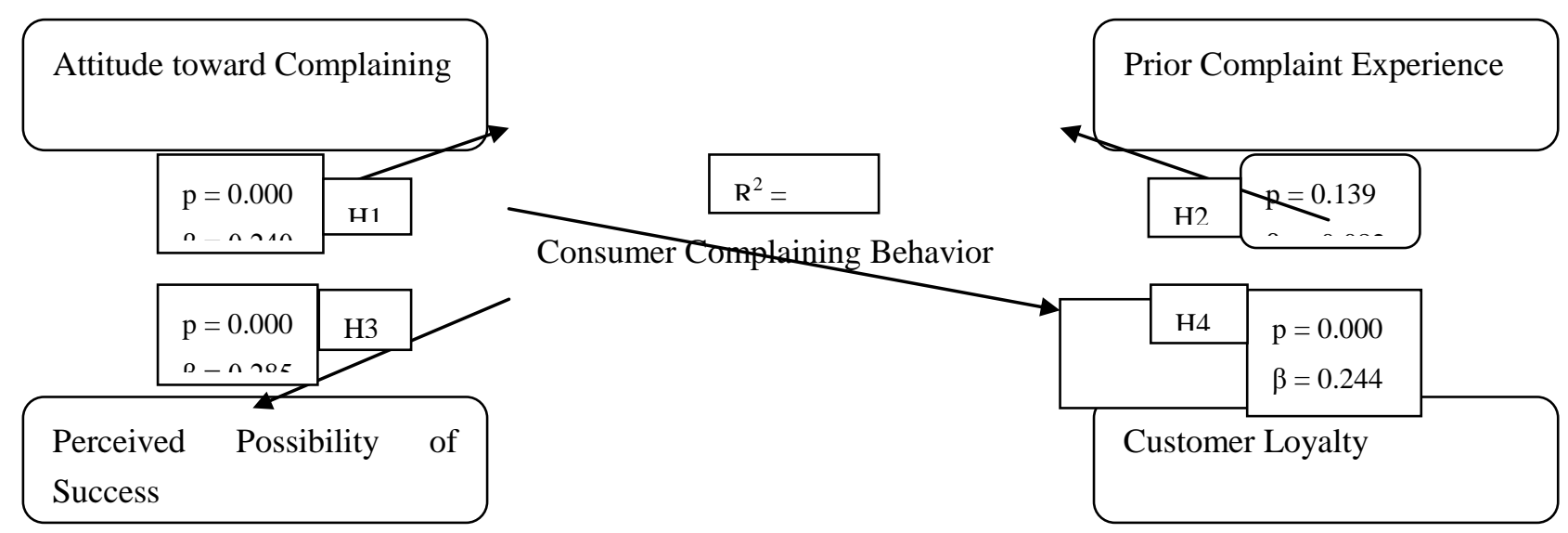




\section{Discussion}

Empirical studies in the current research prove that 'attitude toward complaining', 'perceived possibility of success', 'prior complaint experience' and 'customer loyalty' are important determinants that affect consumer complaining behavior. This research focuses on how attitudinal and perceptional variables enhance consumer complaining behavior. As discussed Singh and Wilkies (1996), our study indicates that consumer complaining behavior as the dependent variable is successfully predicted by attitudinal and perceptional variables. Healthy linear correlation value of (0.327) proves this claim, which indicates that $32.7 \%$ of the total variance in consumer complaining behavior is accounted for by the variables of our proposed model. Demographic variables also have an impact on relationship between dependent and independent variables but significant effect of perceived possibility of success and customer's loyalty indicate that the independent variables of our research predict consumer complaining behavior without influence from demographic factors.

Perceived likelihood of success has been one of the most relevant variables in the formation of consumer complaining behavior (Singh \& Wilkes, 1996). Perceived possibility of success has proved to be the determining factor with the greatest influence on consumer complaining behavior in our research.

In the past research work we have studied, loyal customers always have positive attitude toward the company as well as they do not give value to pricing and do not switch to other competitors (Eggert, 2000). There is a strong association between the customer's loyalty and consumer complaining behavior and similar is proved by our research. Customer's loyalty has proved to be second greatest contributing factor to affect consumer complaining behavior.

Empirical researchers have found that there is a direct positive impact of attitude toward complaining and consumer complaining behavior (Singh, 1989). Some also suggested that in relationship of attitude toward complaining and consumer complaining behavior, complaint intentions act as mediator (Singh, 1990a). Attitude toward complaining has proved to be the third most relevant factor to influence consumer complaining behavior.

Past complaint experience of a customer gives an idea of his future complaints (Singh, 1989). In other words, customers having this experience know how to complain. According to Singh and Wilkies (1996), there must be a relationship between past experience and attitude; because if they know how to complain due to the past experience, there will be more positive attitude toward complaining this time. This tells us that past experience have a positive impact on consumer complaining behavior. But our study does not show any significant relationship between past experience and consumer complaining behavior. This research has been conducted in a small city of Pakistan. In Pakistan, most of the service providers, unlike service providers in European countries, try to escape from service recovery in order to cut the cost related with service recovery. Failed service encounters often result in negative emotions, in particular when fairness is lacking in recovery effort (McColl_Kennedy \& Sparks, 2003). Our culture is a collectivist culture. In a collectivist culture, people hesitate to complain to service providers again due to face saving, interpersonal harmony and reciprocity. (Le Clare, 1993). 


\section{Limitations and Future Research}

Aim of our study has been to increase the knowledge of consumer complaining behavior by studying how it is produced as a result of dissatisfaction. Consumer complaining behavior has proved to be comprising of Voicing, Negative word-of-mouth and third party action. Future research can explore the effect of the discussed attitudinal and perceptional variables on these three constituents of consumer complaining behaviors individually. More studies can explore the causes of these three types of consumer complaining behaviors expressed as a result of dissatisfaction.

\section{Works Cited}

Anton, C., Camarero, C., \& Carrero, M. (2007). Analysing firms' failures as determinants of consumer switching intentions: the effect of moderating factors. European Journal of Marketing , 135-58.

Bearden, W. O., \& Teel, J. E. (1980). An investigation of personal influences on consumer complaining. Journal of Retailing , 3-20.

Bitner, M. J., Booms, B. H., \& Tetreault, M. S. (1990). The service encounter: diagnosing favorable and unfavorable incidents. Journal of Marketing , 71-84.

Blodget, G. J., Granbois, D. H., \& Walters, R. G. (1993). The effects of perceived justice on complainnants' negative word of mouth behavior and repatronage intentions. Journal of Retailing , 414.

Blodget, J., \& Anderson, R. (2000). A bayesian model of consumer complaint process. Journal of service research, 321-38.

Blodget, J., \& Granbois, D. (1992). Toward an integrated conceptual model of consumer complaining behavior. Journal of consumer Satisfaction, Dissatisfaction and Complaining behavior, 93-103.

Bodey, K., \& Grace, D. (2007). Contrasting complainers with non-complainers on attitude toward complaining, propensity to complain and key personality characteristics nomological look. Journal of Psychology and Marketing , 179-94.

Bolfing, C. P. (1989). How do customers express dissatisfaction and what can service marketers do about it? Journal of Service Marketing , 5-23.

Bone, P. F. (1995). Word of mouth impacts on short term and long term product judgement. Journal of Business Research, 213-23.

Brooks, R. L. (2010). The power of loyalty. Binghamton: Entreprenuer Press.

Chan, H., \& Wan, L. (2008). Consumer responces to service failures: a resource preference model of cultural influences. Journal of International Marketing , 72-97.

Chelminski, P., \& Coulter, R. A. (2007). The effects of cultural individualism and 
self-confidence on propensity to voice: from theory to measurement to practice. Journal of International Marketing , 94-118.

Cocroft, B., \& Ting-Toomi, S. (1994). Face work in Japan and United States. International Journal of International Relations , 469-506.

Day, R. L., \& Bodur, M. (1978). Consumer response to dissatisfaction with service and intangibles. Advances in Consumer Research, 263-72.

Day, R. L., \& Landon, E. L. (1976). Collecting comprehensive consumer complaint data by servey research. Advances in Consumer research, 263-8.

Day, R. L., \& Landon, E. L. (1977). Towards a theory of consumer complaining behavior.

Day, R. L., Grabicke, K., Schaetzle, T., \& Staubach, F. (1981). The hidden agenda of consumer complaining. Journal of Retailing , 86-106.

Durukan, T., Gokdeniz, I., \& Bozaci, I. (2012). Situational factors affecting Customer complaining propensity to firm. Business Management Dynamics , 26-32.

Eggert, A. (2000). Konzeptualisierung und Operationalisierung der Kundenbindungaus Kundensicht. Marketing ZFP , 119-30.

Fishbein, M., \& Ajzen, I. (1975). Belief, Attitude, Intention and Behavior: An introduction to theory and research.

Fornell, C., \& Wernerelt, B. (1988). A model for customer complaint management. Marketing Science, 287-98.

Rizwan, M., Khan, A., Saeed, I., Shah, K., Azhar, N. \& Anam, W. (2013) Determinants of Customer Complaining Behavior, International Journal of Research in Computer Applications and Management, 3(3), 119-124

Gregoire, Y., \& Fisher, R. J. (2008). Customer betrayal and retaliation: when your best customers become your worst enemies. Journal of Academy of Marketing Science , 247-61.

Hirschman, A. O. (1970). Exit, voice and loyalty: responses to decline in firms, organizations and states.

Huang, J. H., T., H. C., \& Wu, S. (1996). National character and response to unsatisfactory hotel service. International Journal of Hospitality Management, 229-43.

Hui, M., Ho, C., \& Wan, L. (2011). Prior relationships and consumer responses to service failures: a cross-cultural study. Journal of International Marketing , 59-81.

Huppertz, J. (2007). Firms' complaint handling policies and consumer complaint voicing. Journal of consumer marketing, 428-37.

Hwang, A., Francesco, A., \& Kessler, E. (2003). The relationship between individualism, collectivism, face and feedback and learning processes in HongKong, Singapore and the United States. Journal of Cross Cultural Psychology, 72-91. 
Jin, L. Y. (2010). Determinants of customer's complaint intention. Nankai Business Review International, 87-99.

Jin, L. Y. (2010). Determinants of customer's complaint intention: Empirical study in the context of China's retail industry. Nankai Busuness Review International , 87-99.

Kim, C., Kim, S., Im, S., \& Shin, C. (2003). The affect of attitude and perception on consumer complaint intention. Journal of Consumer Marketing , 352-71.

Kim, G. M., Wang, C., \& Mattila, A. S. (2010). The relationship between consumer comlaining behavior and service recovery: an integrative review. Internatinal Journal of Contemporary Hospitality Management, 975-91.

Kowalski, R. M. (1996). Complaints and complaining: functions, antecedents and consequences. Psychological Bulletin , 179-96.

Krapfel, R. E. (1985). A consumer complaint strategy model: antecedents and outcomes. Advances in consumer Research, 346-50.

Le Clare, K. A. (1993). Chinese Complaints behavior. Journal of International Consumer Marketing , 73-92.

Martin, N. I. (1991). Expert-novice differences in complaint scripts. Advances in Consumer Research, 225-31.

Mattila, A. S. (2004). The impact of service failures on customer loyalty: the moderating role of effective commitment. International Journal of Service Industry Management , 134-49.

Maute, M., \& Forrester, W. R. (1993). The structure and determinants of consumer complaint intentions and behavior. Journal of economic Psychology, 219-47.

McColl_Kennedy, J. R., \& Sparks, B. A. (2003). Application of fairness theory to service failures and service recover. Journal of Service Research , 251-61.

Mittal, V., Huppertz, J., \& Khare, A. (2008). Customer complaining: role of tie strength and information control. Journal of Retailing , 195-204.

Morel, K. P., Posez, T. B., \& Wilke, H. A. (1997). Motivation, Capacity and opportunity to complain: towards a comprehensive model of consumer complaint behavior. Advances in Consumer Research , 464-9.

Nicholson, C., Compeau, L., \& Sethi, R. (2001). The role of interpersonal liking in building trust in long-term channel relationships. Journal of the Academy of Marketing Science , 3-15.

Oh, D. G. (2004). Complaining behavior of academic library users in South Korea. The Journal of Academic Librarianship , 136-44.

Oh, D. G. (2003). Complaining behavior of public library users in South Korea. Library and Information Science Research , 43-62.

Oliver, R. L. (1997). Satisfaction: A behavioral perspective on the consumer. New York, NY: 
The Mcgrawth hill companies.

Oztopcu, A. (2006). Müşteri şikâyet toplama yöntemleri ve hizmet personelinin etkisi lokantacılık sektöründe bir araştırma. Eskişehir Osmangazi University.

Panther, T., \& Farquhar, J. D. (2004). Consumer responses to dissatisfaction with financial service provider: an exploration of why some stay while others switch. Journal of Financial Service Marketing , 343.

Phau, I., \& Sari, R. (2004). Engaging in complaint behavior. Marketing intelligence and planning , 407.

Richins, M. L. (1987). A multivariate analysis of responses to dissatisfaction. Journal of Academy of Marketing Science, 24-31.

Richins, M. L. (1980). Consumer perceptions of costs and benefits associated with complaining. Refining concepts and measures of Consumer Satisfaction and Complaining Behavior , 50-3.

Rogers, J. C., Ross, S. C., \& Williams, T. G. (1992). Personal values and purchase dissatisfaction response. Journal of consumer satisfaction, dissatisfaction and complaining behavior, 81-92.

Schouten, V., \& Raaij, W. F. (1990). Consumer problems and dissatisfaction in retail settings. Journal of Consumer Satisfaction, dissatisfaction and Complaining Behavior, 56-60.

Singh, J. (1988). consumer complaint intention behavior: definitional and taxonomical issue. Journal of Marketing , 93-107.

Singh, J. (1989). Determinants of consumers' decisions to seek third party redress: an empirical study of dissatisfied patients. Journal of Consumer Affairs , 329-63.

Singh, J. (1990a). Voice, exit and negative word of mouth behaviors: an investigation across three service categories. Journal of the Academy of Marketing Science, 1-15.

Singh, J., \& Wilkes, R. E. (1996). When consumers complain: a path analysis of the key antecedents of consumer complaint response estimates. Journal of the Academy of Marketing Science, 350-65.

Steenkamp, J., Hofstede, F., \& Wedel, M. (1999). A cross national investigation into the individual and national culture antecedents of consumer innvativeness. Journal of Marketing , 55-69.

TARP. (1985). Consumer Complaint handling in America: An update study (Part 1). Washington, D. C.: Technical Assistance Research Program.

TARP. (1981). Measuring the grapevine consumer response and word of mouth. Washington, DC: US office of consumer affairs.

Usric, M. (1985). A model of the consumer decision to seek legal redress. Journal of Consumer Affairs , 20-35. 


\section{Macrothink}

International Journal of Learning \& Development

ISSN 2164-4063 2013, Vol. 3, No. 6

Yaping, C., Shaolong, H., \& Xing, Y. (2009). An empirical research on the mechanism of service recovery and customer loyalty in network retail. 1-4.

Yuksel, A., Kilinc, U., \& Yuksel, F. (2006). Cross-national analysis of hotel customers' attitudes toward complaining and their complaining behavior. Tourism Management , 11-24. 